\title{
ERRATUM: Change in Authorship
}

Korean Journal of Acupuncture Vol.31, No.4, pp.218-224, 2014

ORIGINAL ARTICLE

\section{붉은 덕다리버섯 발효 대조(大柬)의 예쁜꾜마선충 수명연장효과}

\author{
지병욱 ${ }^{1} \cdot$ 박성민 $^{2} \cdot$ 구성태 $^{1} \cdot$ 임병묵 $^{3} \cdot$ 유영법 $^{4}$
}

${ }^{1}$ 부산대학교 한의학전문대학원 경락구조의학부, ${ }^{2}$ (주코씨드바이오팜, ${ }^{3}$ 부산대학교 한의학전문대학원 인문사회의학부, ${ }^{4}$ 남부대학교 한방제약개발학과

\section{Lifespan Extension of Fermented Zizyphus jujuba Fruits in Caenorhabditis elegans}

\author{
Byeong-Uk Ji ${ }^{1}$, Sung-Min Park ${ }^{2}$, Sungtae Koo ${ }^{1}$, Byungmook Lim ${ }^{3}$, Young-Beob Yu ${ }^{4}$ \\ ${ }^{1}$ Division of Meridian and Structural Medicine, School of Korean Medicine, Pusan National University, \\ ${ }^{2}$ CoSeed BioPharm Corporation, ${ }^{3}$ Division of Humanities and Social Medicine, School of Korean Medicine, \\ Pusan National University, ${ }^{4}$ Department of Herbal Pharmaceutical Development, Nambu University
}

The authors of "Lifespan Extension of Fermented Zizyphus jujuba Fruits in Caenorhabditis elegans" (Korean J. Acupunct. 2014 31:(4) 218-224) requested for removal of an author (Byungmook Lim) due to the difference in interpretation of data. The corrected authorship should be as follows:

\author{
지병욱 ${ }^{1} \cdot$ 박성민 $^{2} \cdot$ 구성태 $^{1} \cdot$ 유영법 $^{3}$ \\ ${ }^{1}$ 부산대학교 한의학전문대학원 경락구조의학부, ${ }^{2}$ (주)코씨드바이오팜, ${ }^{3}$ 남부대학교 한방제약개발학과
}

Byeong-Uk Ji ${ }^{1}$, Sung-Min Park ${ }^{2}$, Sungtae Koo ${ }^{1}$, Young-Beob Yu ${ }^{3}$

${ }^{1}$ Division of Meridian and Structural Medicine, School of Korean Medicine, Pusan National University,

${ }^{2}$ CoSeed BioPharm Corporation, ${ }^{3}$ Department of Herbal Pharmaceutical Development, Nambu University 